\title{
Exosome-Encapsulated MicroRNA-2I from Esophageal Squamous Cell Carcinoma Cells Enhances Angiogenesis of Human Umbilical Venous Endothelial Cells by Targeting SPRYI [Retraction]
}

\author{
Zhuang H, Wang H, Yang H, Li H. Cancer Manag Res. 2020;12:10651-10667.
}

At the authors request, the Editor and Publisher of Cancer Management and Research wish to retract the published article. The authors have informed the journal that they have concerns with the reliability of the published results and they cannot provide any original data relating to their study and can no longer verify the findings as reported. In addition, the authors have advised they did not obtain ethics approval from the Ethics Committee of Linyi People's Hospital to conduct the animal experiments and the Hongjun Wang and Haibo Yang were added as authors without their knowledge or approval. The authors wish to apologize for this.

The Editor has agreed with the request to retract the article.

Our decision-making was informed by our policy on publishing ethics and integrity and the COPE guidelines on retraction.

The retracted article will remain online to maintain the scholarly record, but it will be digitally watermarked on each page as "Retracted".

\section{Publish your work in this journal}

Cancer Management and Research is an international, peer-reviewed open access journal focusing on cancer research and the optimal use of preventative and integrated treatment interventions to achieve improved outcomes, enhanced survival and quality of life for the cancer patient. The manuscript management system is completely online and includes a very quick and fair peer-review system, which is all easy to use. Visit http://www.dovepress.com/testimonials.php to read real quotes from published authors. 